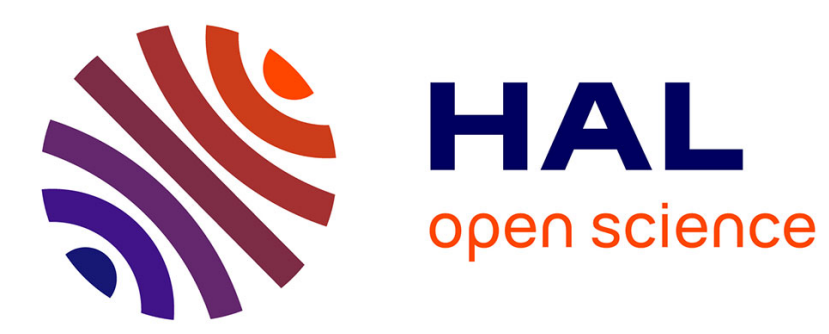

\title{
Transverse shrinkage in G-fibers as a function of cell wall layering and growth strain
}

Chang-Hua Fang, Bruno Clair, Joseph Gril, Tancrède Alméras

\section{To cite this version:}

Chang-Hua Fang, Bruno Clair, Joseph Gril, Tancrède Alméras. Transverse shrinkage in G-fibers as a function of cell wall layering and growth strain. Wood Science and Technology, 2007, 41 (8), pp.659-671. 10.1007/s00226-007-0148-3 . hal-00194930

\section{HAL Id: hal-00194930 \\ https://hal.science/hal-00194930}

Submitted on 7 Dec 2007

HAL is a multi-disciplinary open access archive for the deposit and dissemination of scientific research documents, whether they are published or not. The documents may come from teaching and research institutions in France or abroad, or from public or private research centers.
L'archive ouverte pluridisciplinaire HAL, est destinée au dépôt et à la diffusion de documents scientifiques de niveau recherche, publiés ou non, émanant des établissements d'enseignement et de recherche français ou étrangers, des laboratoires publics ou privés. 


\title{
G-layer transverse shrinkage and its consequences on shrinkage of poplar tension wood
}

\author{
Chang-Hua FANG ${ }^{1,2}$, Bruno CLAIR ${ }^{1}$, Joseph GRIL $^{1}$, Tancrède ALMERAS ${ }^{3}$ \\ 1) Laboratoire de Mécanique et Génie Civil, Université Montpellier 2, France \\ 2) Forest Products Department, Anhui Agricultural University, Hefei, China \\ 3) UMR Ecologie des Forêts de Guyane,- BP 709, 97387 Kourou cedex, French Guiana \\ Corresponding author: Chang-Hua FANG \\ e-mail: fang@lmgc.univ-montp2.fr \\ Tel: $\quad+33-467144918$ \\ Fax: $\quad+33-467144792$
}

\begin{abstract}
Transverse drying shrinkage was measured at microscopic and mesoscopic levels in poplar wood characterised by an increasing growth strain (GS), from normal to tension wood. Results show that: (a) The drying shrinkage, measured as a relative thickness decrease, was significantly higher for G-layer (GL) than the other layers (OL), GL shrinkage was not significantly correlated with GS and OL shrinkage was negatively correlated with GS. (b) In gelatinous fibre (G-fibre), lumen size increased during drying and this increase was positively related with GS, but in normal wood fibre lumen size decreased during drying. These findings suggest that GL shrank outwards, so that its shrinkage feebly affected the total cell shrinkage and the mesoscopic shrinkage was controlled by the OL shrinkage which shrank inwards. (c) Measurements done on $7 \times 7 \mathrm{~mm}^{2}$ thin sections evidenced a negative correlation between transverse shrinkage and GS, significant in T direction but weak in R direction. These observations at both levels allow to discuss the contribution of GL to the mesoscopic shrinkage of tension wood.
\end{abstract}

Key-words: poplar wood, G-fibre, G-layer, growth strain, shrinkage, tension wood

\section{INTRODUCTION}

Tension wood is a peculiar wood tissue that often forms in the upper side of leaning trunks and branches in hardwood species (Isebrands and Bensend 1972) and generates high tensile stress (Wardrop 1964; Fisher and Stevenson 1981) that assists stems or branches to maintain or recover a preferred orientation (Kuo and Timell 1969). It exhibits important changes of the cell wall structure compared with normal wood (Onaka 1949). Normal wood fibres are composed of a middle lamella, a fine primary layer and a large secondary layer (S) divided into 3 sub-layers, called $S_{1}, S_{2}$ and $S_{3}$. In many species such as beech, poplar, oak or chestnut, tension wood contains fibres with a special morphology and chemical composition due to the development of the so-called gelatinous layer (G-layer, noted here GL) replacing $\mathrm{S}_{3}$ and a part or the whole of $S_{2}$ (Saiki and Ono 1971). The GL is known to have a high cellulose content with a high degree of crystallinity (Norberg and Meier 1966; Côté et al. 1969) and to contain microfibrils oriented along the axis of the cell (Fujita et al. 1974). In this study, the cell wall is considered as composed of 2 parts: the GL and the other layers (noted OL). OL includes the compound middle lamella (CML) and the sub-layers of S, excluding GL.

This study will focus on the drying shrinkage of tension wood compared with normal wood. Because of its technological consequences, macroscopic longitudinal shrinkage of tension wood has been much more studied than its transverse shrinkage. Tension wood is known to exhibits a higher longitudinal shrinkage than normal wood (Clarke 1937; Chow 1946; Sassus 1998; Jourez et al. 2001; Clair et al. 2003b). This result is paradoxical considering the low microfibrillar angle (MFA) in tension wood and the usual positive correlation between MFA and longitudinal shrinkage (Meylan 1972; Timell 1986). Experimental evidence of longitudinal shrinkage of GL itself has been given by Clair and Thibaut (2001) but without explanation of the mechanism. Few studies have been done on the transverse shrinkage of tension wood and the results are contradictory. Washusen and Ilic (2001), Clair et al. (2003a; 2003b) reported a higher transverse shrinkage in tension wood, while Arganbright et al. (1970) and Barefoot (1963) observed a lower shrinkage in maple tension wood. In this study, we 
hope to throw some light on these contradictory results by focusing on the transverse shrinkage at the cell wall layers level. Contrary to Norberg and Meier (1966) who measured the shrinkage of isolated GL, this work considers GL shrinkage in its cellular context. This should allow to understand the consequences of the shrinkage of the cell wall layers on the shrinkage at the tissue level. The method used will also allow to avoid the swelling artefact of GL during sample preparation (Clair et al. 2005b) and therefore to obtain quantitative measurements of GL shrinkage. Samples of this study have been chosen according to the residual growth strain measured on the living tree. It is expected that variations of GL shrinkage will yield qualitative information on the change (or not) in GL structure depending on the stress level. Does GL structure differ between mild and strong tension wood? What are the respective roles of GL and OL in the global shrinkage of tension wood? In order to answer these questions, the shrinkage will be measured both at cell wall layer and tissue levels, in normal wood and for different levels of tension wood.

\section{MATERIEL AND METHODS}

Experiments have been performed on normal and tension wood of poplar (Populus cv. I4551). This species is known to produce tension wood containing a characteristic GL and associated with a high longitudinal tensile stress. One 15 years old tree was chosen according to its tilted shape.

\section{Growth Strain (GS) measurements}

The strain gage method (Yoshida and Okuyama 2002) was used to estimate the longitudinal residual growth strain (GS) at 25 positions around the surface of an inclined poplar trunk at different heights. The GS values are good indicators of the growth stress level within trees of the same species (Fournier et al. 1994). GS is expressed in microstrain dimensionless unit $(\mu \varepsilon=\mu \mathrm{m} / \mathrm{m})$. All the values being negative, absolute GS values will be used to simplify representations and analysis. GS values ranging from $100 \mu \varepsilon$ to $2275 \mu \varepsilon$ were obtained.

\section{Shrinkage measurement at microscopic level}

Samples (one for each GS value, $5 \times 5 \times 5 \mathrm{~mm}^{3}$ ) were taken from GS measurement positions. They were maintained in water as soon as they were taken out from the tree. None or very few gelatinous fibres (G-fibre) were found under microscope after sectioning the samples with GS equal or less than $610 \mu \varepsilon$. Thus, 6 samples were chosen for experiments with GS values equidistributed from 610 to $2275 \mu \varepsilon(610,816,1158,1450,1935$ and $2275 \mu \varepsilon)$.

As normal sectioning method with a sliding microtome results in an uncontrolled swelling and detachment of GL (Clair et al. 2005b; Clair et al. 2005a), embedded wood samples were used and serial-sectioning was performed with glass knife.

Wood sticks ( $2 \mathrm{~mm}$ in longitudinal direction, $1 \mathrm{x} 1 \mathrm{~mm}^{2}$ in cross section) were longitudinally cut by splitting to guarantee a good axial orientation. To avoid shrinkage, the samples were always kept in a drop of water during the preparation. They were then cut in the middle of axial direction, perpendicular to the fibres, with a brand new razor blade in order to obtain two matched samples. One sample was dehydrated with ethanol series, then embedded in LR White resin (two exchanges of resin/ethanol mixture for 1 hour, followed by two exchanges in pure resin for 1 hour, kept one day at room temperature, then kept overnight in a capsule at $65^{\circ} \mathrm{C}$ ), the other one was oven dried and then embedded in LR White resin (two exchanges in pure resin for 1 hour, kept one day at room temperature, then kept overnight in a capsule at $65^{\circ} \mathrm{C}$ ) (Fig. 1). After polymerisation of the resin, all deformations of the tissue are blocked, so that sectioning does not alter the shape and the size of the cell wall layers. This method allows observations of the cells from the border to the core of the sample, keeping the morphology as it was before embedding. In the following, the data obtained with the first specimen will be referred as "wet" values, considering that the replacement of water by ethanol did not alter significantly the cellular morphology of the never-dried wood, and the data obtained with the oven dried specimen as "dry" values. 


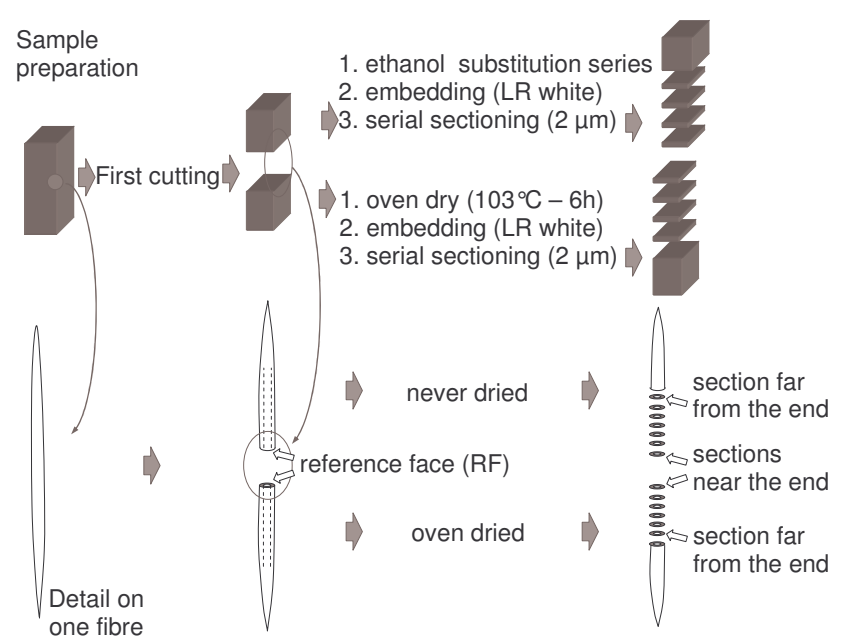

Fig. 1. Experimental protocol and terminology used in the article (Clair et al. 2005a).

Serial cross-sectioning ( $2.5 \mu \mathrm{m}$ thickness) was performed with a glass knife and the distance to the initial border of the sample was noted for each section. For each sample more than 100 sections were made to ensure that measured sections were far enough from the sample border and avoid the border artefact. Sections were mounted on glass slides and observed under optical microscope.

Images (Fig. 2a) were obtained with a digital camera and measurements were performed with image analysis software Image J (Rasband 1997-2006).

First, measurements were done on 12 fibres per sample to compare the wet and dry wall thickness of the same fibre. However, because of the non-uniformity of the walls thickness along the fibres (Okumura et al. 1977), the thickness values were not comparable. So, statistical trends were searched from new measurements with more repetitions. 25 to 30 measurements of the double cell wall thickness excluding $\left(\mathrm{L}_{1}\right)$ or including $\mathrm{GL}\left(\mathrm{L}_{2}\right)$, as well as of lumen perimeter were performed in each sample in both wet and dry states (Fig. 2b). From these measurements, morphometric parameters were obtained as follow:

All layer $(\mathrm{AL})$ thickness $=L_{2} / 2$

OL thickness $=L_{1} / 2$

GL thickness $=\left(L_{2}-L_{1}\right) / 2$

Based on the mean values of these parameters for a given sample, the radial cell-wall shrinkage of AL, OL or GL were calculated as the relative thickness decrease between the wet and dry condition. The relative lumen perimeter decrease was used to estimate the tangential cell-wall shrinkage at the inner side of the cell wall.
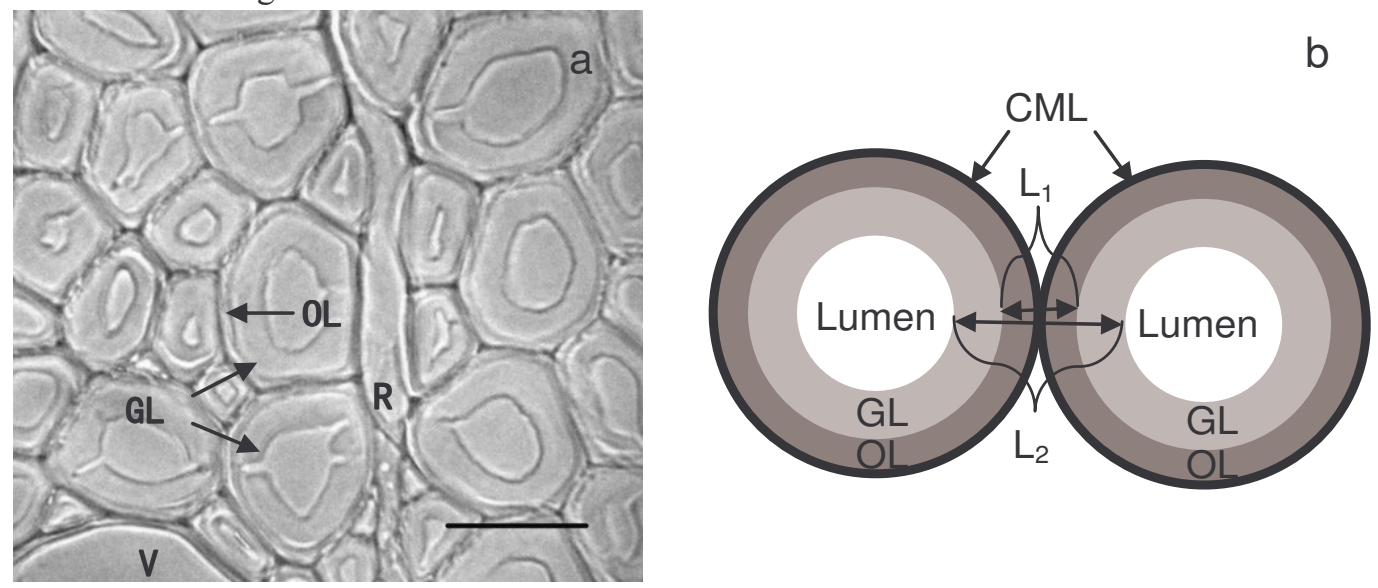

Fig. 2. Shrinkage measurement at the cell wall level. GL: G-layer; OL: other cell wall layers, including compound middle lamella (CML), S1 and S2; V: vessel; R: ray; a: Transverse section picture. Scale bar $=20 \mu \mathrm{m}$. b: Morphological model and parameters. $\mathrm{L}_{1}$ : Double $\mathrm{OL}$ thickness; $\mathrm{L}_{2}$ : Double all layer (AL) thickness. 


\section{Shrinkage measurement at mesoscopic level}

Samples were taken in the vicinity of the sample used for the microscopic study. Two additional samples were selected to enlarge the spectrum of values including normal wood. Thus, GS values of the chosen samples are $168 \mu \varepsilon, 405 \mu \varepsilon, 610 \mu \varepsilon, 816 \mu \varepsilon, 1158 \mu \varepsilon, 1450 \mu \varepsilon$, $1935 \mu \varepsilon$ and $2275 \mu \varepsilon$. The 5 last samples contained G-fibres, and the first 3 (here called normal wood) did not. Wood sticks $\left(7 \times 7 \mathrm{~mm}^{2}\right.$ in cross section) were sectioned ( $20 \mu \mathrm{m}$ thick) with a sliding microtome. Two sections for each sample were selected and mounted on glass slides with a drop of water to avoid drying, and covered with cover-glass to prevent warping. A very light press was performed with fingers on the cover-glass in order to level up the wood sections. Images covering the whole cross sections were taken under microscope before and after the sections were oven dried.

On the images before and after drying, corresponding pairs of points were chosen and their distances were measured using the image analysis software Image J (Rasband 1997-2006). The shrinkage was calculated as the relative distance decrease. For each sample 10 measurements were done in tangential $(\mathrm{T})$ and 10 in radial $(\mathrm{R})$ direction.

\section{Results and discussion}

\section{GS - Cell wall radial shrinkage}

Fig. 3 shows the average values and 95\% confidence intervals of GL, OL and AL thickness for different GS levels in wet and dry conditions (as none or very few GL was found in the sample with a GS of $610 \mu \varepsilon$ the GL thickness was regarded as 0 and thereby AL thickness equalled that of $\mathrm{OL}$ ).

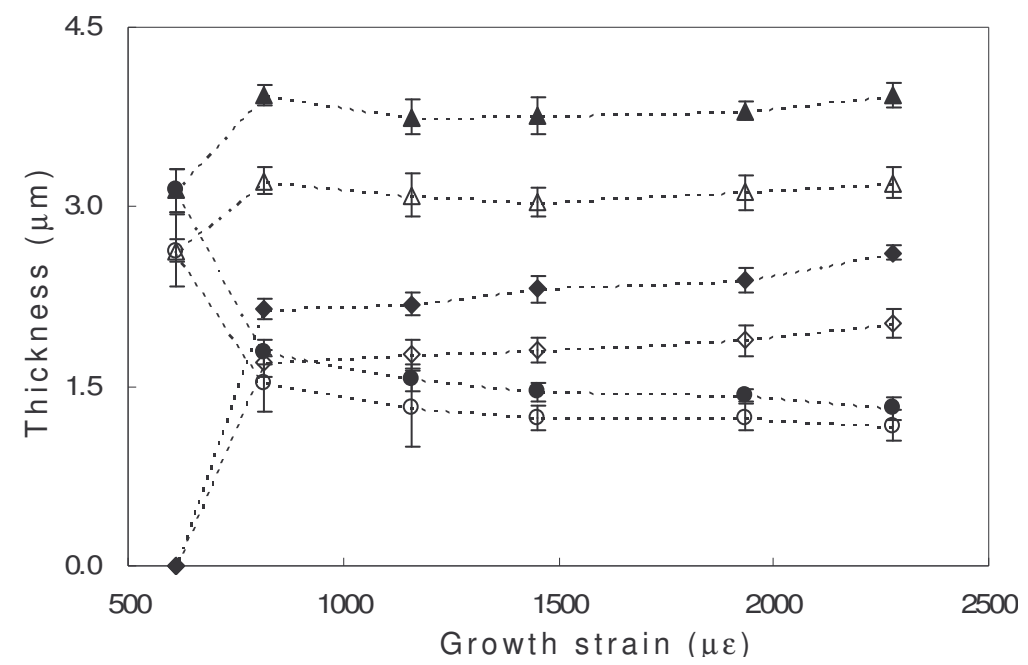

Fig. 3. Thickness variations of GL, OL and AL for different growth strains in wet and dry conditions. $\bullet$ : AL wet. ; $\square$ : AL dry; $\square$ : GL wet; $\square$ : GL dry; •: OL wet; ॰: OL dry. Error bars show $95 \%$ confidence intervals.

OL thickness decreased markedly from normal wood to tension wood (Fig. 3). This confirms that in tension wood, GL replaces a part or the whole of the $S_{2}$ layer (Saiki and Ono 1971). AL thickness in normal wood was notably lower than in tension wood (Fig. 3) indicating that the GL is thicker than the replaced layers which exist in normal fibres.

In the 5 tension wood samples, GL thickness had a significant positive correlation with GS, and OL thickness a significant negative one (Fig. 3, Table 1). These relations were found both in wet and dry conditions. This clearly demonstrates that GS is a reliable indicator of tension wood severity, associated with more and more pronounced morphological changes. AL thickness did not change significantly with GS in either condition (Fig. 3, Table 1). It implies that G-fibres contain a bigger proportion of GL when the samples have higher GS, as shown recently (Fang et al. submitted 2006). 
Table 1. Correlations between parameters for the 5 samples containing G-fibres, except for the underlined values, which include all 6 samples. Correlation coefficients (Pearson) are given in the lower left half of the matrix and significance levels (2-tailed) in the upper right.

\begin{tabular}{|c|c|c|c|c|c|c|c|c|c|c|c|c|}
\hline \multicolumn{3}{|c|}{ Parameters } & $(1)$ & $(2)$ & (3) & (4) & (5) & (6) & (7) & (8) & $(9)$ & (10) \\
\hline \multicolumn{2}{|c|}{ Growth strain $(\mu \varepsilon)$} & $(1)$ & 1 & ** & ** & NS & ** & ** & NS & NS & ** & $\underline{\mathrm{NS}}$ \\
\hline \multirow{6}{*}{ 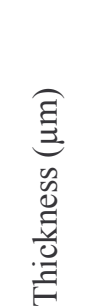 } & GL & $(2)$ & 0.581 & 1 & ** & ** & ** & ** & NS & NS & * & NS \\
\hline & $\mathrm{OL}$ & (3) & -0.532 & -0.415 & 1 & ** & NS & ** & NS & NS & $\underline{\text { NS }}$ & * \\
\hline & $\mathrm{AL}$ & $(4)$ & 0.052 & 0.550 & 0.532 & 1 & NS & NS & * & NS & $\underline{\mathrm{NS}}$ & * \\
\hline & GL & $(5)$ & 0.349 & 0.261 & -0.076 & 0.173 & 1 & NS & ** & NS & - & NS \\
\hline & $\mathrm{OL}$ & $(6)$ & -0.471 & -0.243 & 0.312 & 0.055 & -0.170 & 1 & ** & NS & $\underline{\mathrm{NS}}$ & * \\
\hline & $\mathrm{AL}$ & $(7)$ & 0.005 & 0.074 & 0.134 & 0.188 & 0.773 & 0.494 & 1 & NS & $\underline{\mathrm{NS}}$ & $\underline{\mathrm{NS}}$ \\
\hline \multirow{3}{*}{ 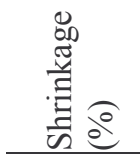 } & GL & (8) & 0.570 & 0.707 & -0.500 & 0.478 & 0.571 & -0.433 & 0.174 & 1 & NS & * \\
\hline & $\mathrm{OL}$ & (9) & -0.923 & -0.955 & $\underline{0.632}$ & -0.616 & -0.934 & $\underline{0.607}$ & -0.595 & -0.699 & 1 & $\underline{\mathrm{NS}}$ \\
\hline & AL & $(10)$ & 0.635 & 0.464 & -0.872 & 0.831 & 0.316 & -0.870 & 0.767 & 0.889 & -0.587 & 1 \\
\hline
\end{tabular}

$\mathrm{NS}=$ not significant, ${ }^{*}=$ significant at 0.05 level, ${ }^{* *}=$ significant at 0.01 level.
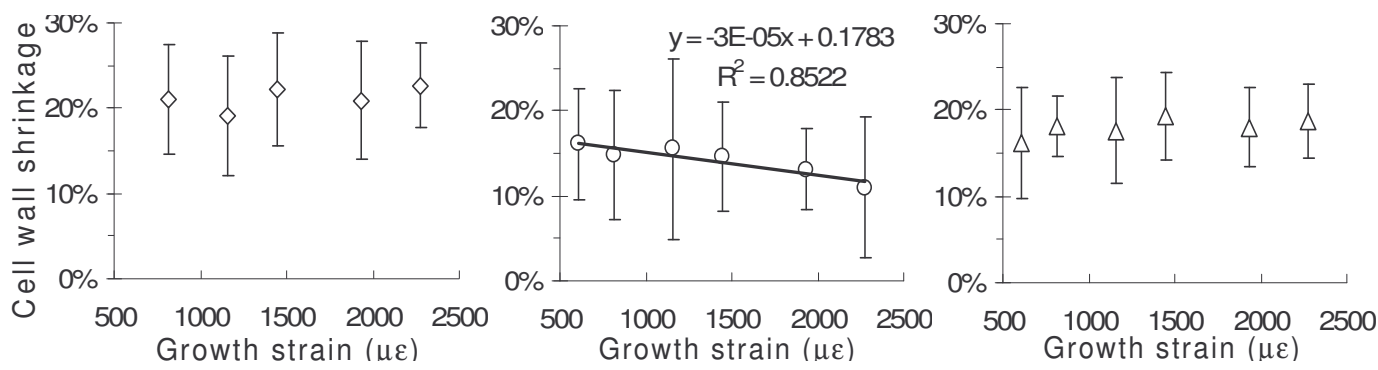

Fig. 4. Relations between GS (in $\mu \varepsilon$ ) and cell wall radial shrinkage. $\square$ : GL ; : OL ; $\square$ : AL. Error bars show $95 \%$ confidence intervals.

Fig. 4 shows the relationship between GS and cell-wall radial shrinkage of GL, OL or AL. Correlation coefficients and significance levels are shown in Table 1. As observed by Norbert and Meier (1966) GL has a very high transverse shrinkage (they measured $15-25 \%$ transverse shrinkage in thickness on isolated GL) compared to other layers. In this study, the shrinkage was also much higher in GL (mean value: $21.2 \%$ ) than in OL (mean value: 14.2\%, Fig. 4). High GL shrinkage could be partly explained by its gel-like structure, and partly by its low lignin content (Furuya et al. 1970; Wada et al. 1995; Pilate et al. 2004) as Bosshard (1956) and Panshin and Zeeuw (1980) proposed that the increase in shrinkage is associated with a decrease in lignin content.

For tension wood samples, GL thickness linearly increased with the increase of GS (Fig. 3), but its shrinkage changed very little (Fig. 4) and no significant correlation was found (Table 1). It suggests that structure and composition of GL do not vary when GS increases but only their thickness. AL shrinkage was not significantly correlated with GS, but related significantly with GL shrinkage for the 5 tension wood samples (Fig. 4, Table 1). High GL proportion in the cell wall can explain this phenomenon.

OL shrinkage had a very significant negative correlation with GS (Fig. 4, Table 1). This fact can be given two explanations.

First, it could be explained by a change in the proportion of CML and $\mathrm{S}_{2}$ in the cell wall. In the cell wall of normal wood, the proportion of CML is very low compared to $\mathrm{S}_{2}$, which plays a dominant role in transverse shrinkage. In tension wood, the higher the GS, the thicker the GL and the thinner the OL (Fig. 3). However, CML seems to remain constant, so that the decrease in OL thickness originates from a decrease in $\mathrm{S}_{2}$ thickness $\left(\mathrm{S}_{2}\right.$ visible in wood with low GS becomes invisible in high GS samples). Matsumoto (cited by Kelsey (1963)) reported that he could not detect any shrinkage in the CML of Japanese red pine, and therefore concluded that the shrinking does not take place in the CML, which is highly lignified, but in $\mathrm{S}$. Then the increase of OL thickness would be linked to the increase of its shrinkage up to a maximum when the CML is negligible compared to $\mathrm{S}_{2}$. This expectation is confirmed by the comparison of OL shrinkage versus its thickness (Fig. 5). 
Second, some authors reported that the concentration of lignin is considerably higher in OL of G-fibres than in the corresponding layers of normal fibres (Timell (1969) cited by Pilate (2004)). So this could be another possible reason for the decrease of OL shrinkage from normal wood to tension wood, as the increase in lignin content is associated with a decrease in shrinkage (Bosshard 1956; Panshin and Zeeuw 1980). But there is no evidence that the concentration of lignin in OL increases with the increase of GS in tension wood.

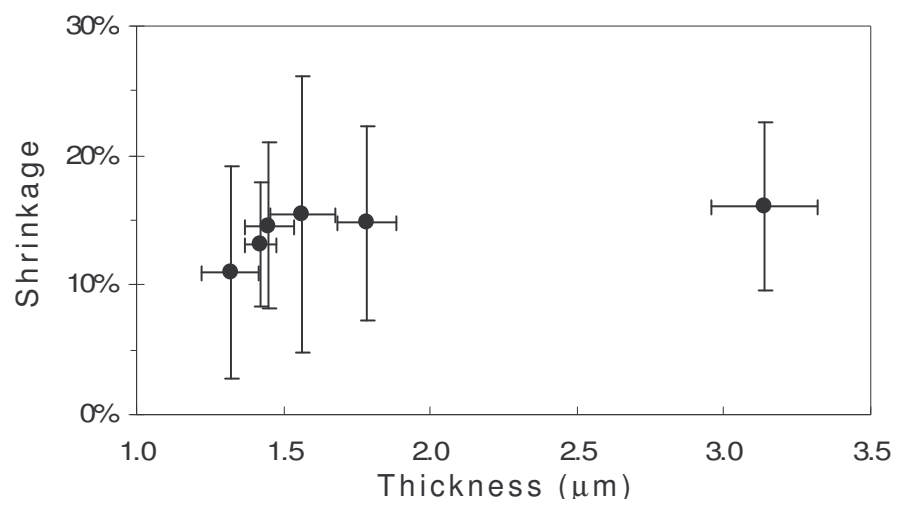

Fig. 5. Relation between the thickness and the shrinkage of the other layers (OL). Error bars show $95 \%$ confidence intervals.

\section{GS - Lumen size change after oven drying}

Some authors observed that in normal wood cell, the lumen size varies only slightly during drying compared to macroscopic shrinkage, reducing in very light wood and augmenting in dense wood (Keylwerth 1951; Kelsey 1963). It indicates that during drying cell wall shrinks inwards: the thickness reduction is driven by the decreases of the external diameter, proportional to the external perimeter. In our study, for the normal wood sample without GL the lumen perimeter reduced nearly by $10 \%$ after oven drying, yielding a positive tangential shrinkage of the inner side of the cell wall (Fig. 6). On the contrary for the G-fibres in tension woods, lumen augmented notably (negative shrinkage) and this effect was stronger with the increase of GS, i.e. with the increase of GL thickness (Figs. 6 and 3). This behaviour of G-fibres can be explained by the combination effect of the absence of $\mathrm{S}_{3}$ layer and the weaker transverse rigidity of G-layer compared to $\mathrm{S}_{2}$.

With these results it can not be concluded whether or not GL also shrinks inwards (its external perimeter decreases), but it can be deduced for certain that it does shrink outwards (its internal perimeter increases). This conclusion will be used in the following discussion of tension wood shrinkage at the mesoscopic level.

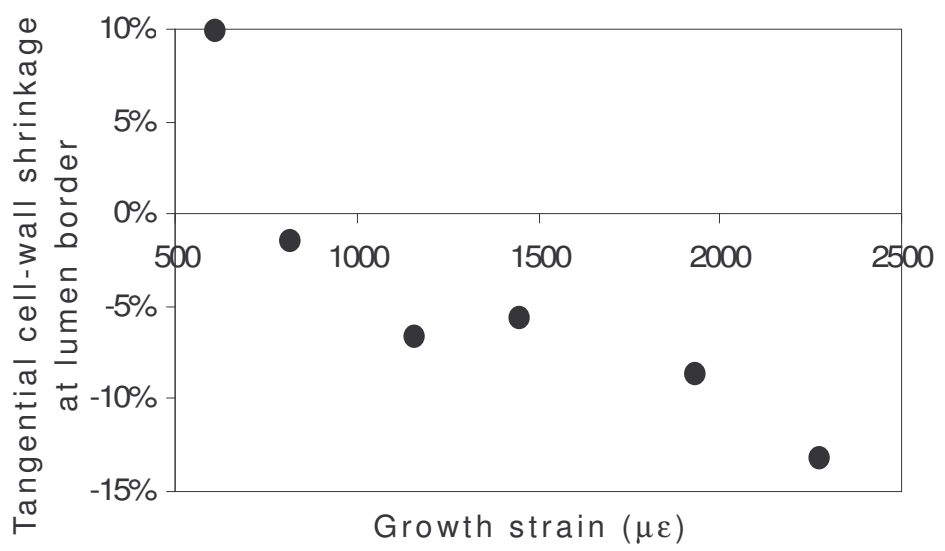

Fig. 6. Tangential cell-wall shrinkages at lumen border for samples with different GS $(\mu \varepsilon)$. Positive value means decrease, negative means increase.

\section{GS - mesoscopic shrinkage}

The means and $95 \%$ confidence intervals of mesoscopic shrinkage in $\mathrm{T}$ and $\mathrm{R}$ direction for 
different GS values are shown in Table 2. The average values of T shrinkage varied from 6.3 to $8.3 \%$, while those of $\mathrm{R}$ shrinkage varied from 3.5 to $4.7 \%$. A paired-samples t-test was performed. The values of $\mathrm{T}$ and $\mathrm{R}$ shrinkage were paired according to the piece of wood from which they originate. The result showed that $\mathrm{T}$ shrinkage was significantly higher than $\mathrm{R}$ shrinkage $(\mathrm{p}<0.001)$. In normal wood $\mathrm{T}$ shrinkage is about 1.4 to 2 times higher than $\mathrm{R}$ one (Kelsey 1963; Panshin and Zeeuw 1980; Skaar 1988); according to our finding hygroexpansion is also highly anisotropic in tension wood.

Table 2. Average values with $95 \%$ confidence interval of section shrinkage in $\mathrm{T}$ and $\mathrm{R}$ directions, for different GS values.

\begin{tabular}{ccccccccc}
\hline Sample number & 1 & 2 & 3 & 4 & 5 & 6 & 7 & 8 \\
\hline Growth strain $(\mu \varepsilon)$ & 168 & 405 & 610 & 816 & 1158 & 1450 & 1935 & 2275 \\
Tangential & 8.33 & 8.25 & 8.00 & 7.15 & 7.20 & 6.42 & 6.43 & 6.29 \\
shrinkage (\%) & \pm 0.41 & \pm 0.47 & \pm 0.36 & \pm 0.32 & \pm 0.44 & \pm 0.40 & \pm 0.38 & \pm 0.38 \\
Radial & 3.99 & 4.68 & 4.29 & 4.06 & 4.65 & 3.47 & 4.33 & 3.47 \\
shrinkage $(\%)$ & \pm 0.29 & \pm 0.18 & \pm 0.34 & \pm 0.45 & \pm 0.17 & \pm 0.15 & \pm 0.42 & \pm 0.30 \\
\hline
\end{tabular}

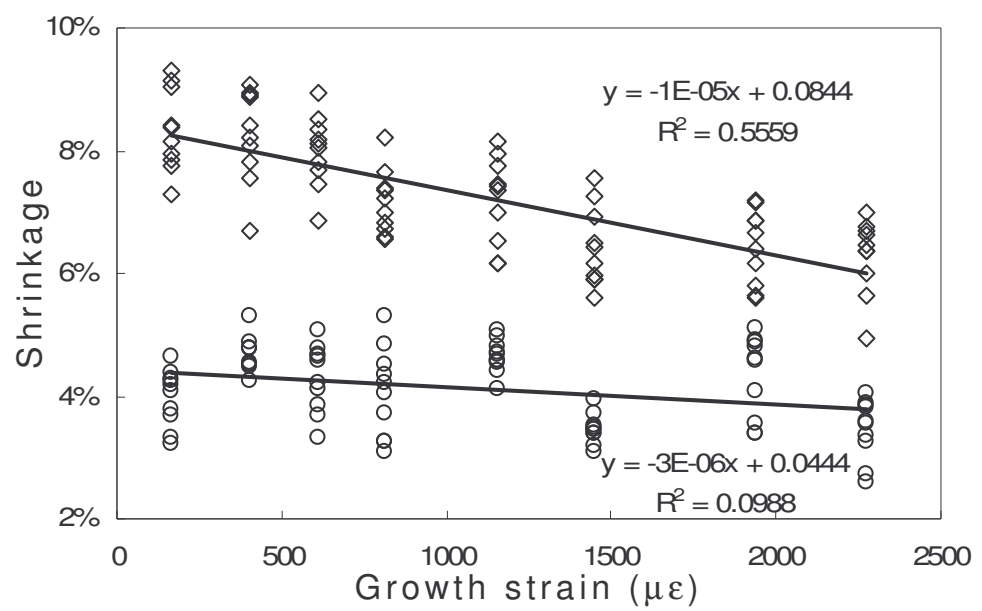

Fig. 7. Tangential ( $\square$ ) and radial (॰) shrinkages versus growth strain.

A very significant negative correlation (Pearson $\mathrm{r}=-0.746, \mathrm{p}<0.001$ with 2-tailed test) was found between T shrinkage and GS (Fig. 7), irrespective of the presence of G-fibres. It indicates that from normal wood to tension wood, $\mathrm{T}$ shrinkage decreases with the increase of GS. This result is contrary to the results from Washusen and Ilic (2001) and Clair et al. (2003b), obtained on massive wood.

A similar but weaker relation (significant at 0.01 level with 2-tailed test, Pearson $\mathrm{r}=-0.314$ ) was found between R shrinkage and GS (Fig. 7). However R shrinkage fluctuated a lot (Fig. 7) and the mean values varied in a very narrow range (Table 2) in spite of a high change of GS. For transverse shrinkage in both $\mathrm{T}$ and $\mathrm{R}$ directions, similar results were reported by Arganbright (1970) and Barefoot (1963) on massive wood of maple and yellow-poplar, respectively, and Barefoot stated that the decrease in $\mathrm{T}$ shrinkage is due to a decrease in specific gravity, while R shrinkage is controlled by fibril angle and specific gravity. The fact that the shrinkage was measured here on sections may have particular mechanical consequences when compared to massive wood. The glass and cover-glass may have kept the section sufficiently plane, nevertheless the section was free from straining in its normal direction, the longitudinal with respect to wood. It was a situation of plane stress, whereas the core of a massive wood would express plane strains; both cases are expected to differ by some Poisson's effects which ought to be checked by further analysis.

We concluded from the above results obtained at microscopic level that during drying the cell wall shrinks inwards in a normal wood cell, but in tension wood the GL shrinks outwards (Fig. 8). This means that GL shrinkage, however big it is, feebly affects the total cell shrinkage and that the mesoscopic shrinkage is controlled by OL shrinkage, which is essentially influenced by the secondary wall shrinkage. The higher the GS, the thinner the secondary wall and the 
lower the transverse shrinkage (Figs. 3 and 4). The difference between T and R shrinkage is supposed to be due to the parenchyma rays which prevent part of the radial strain.

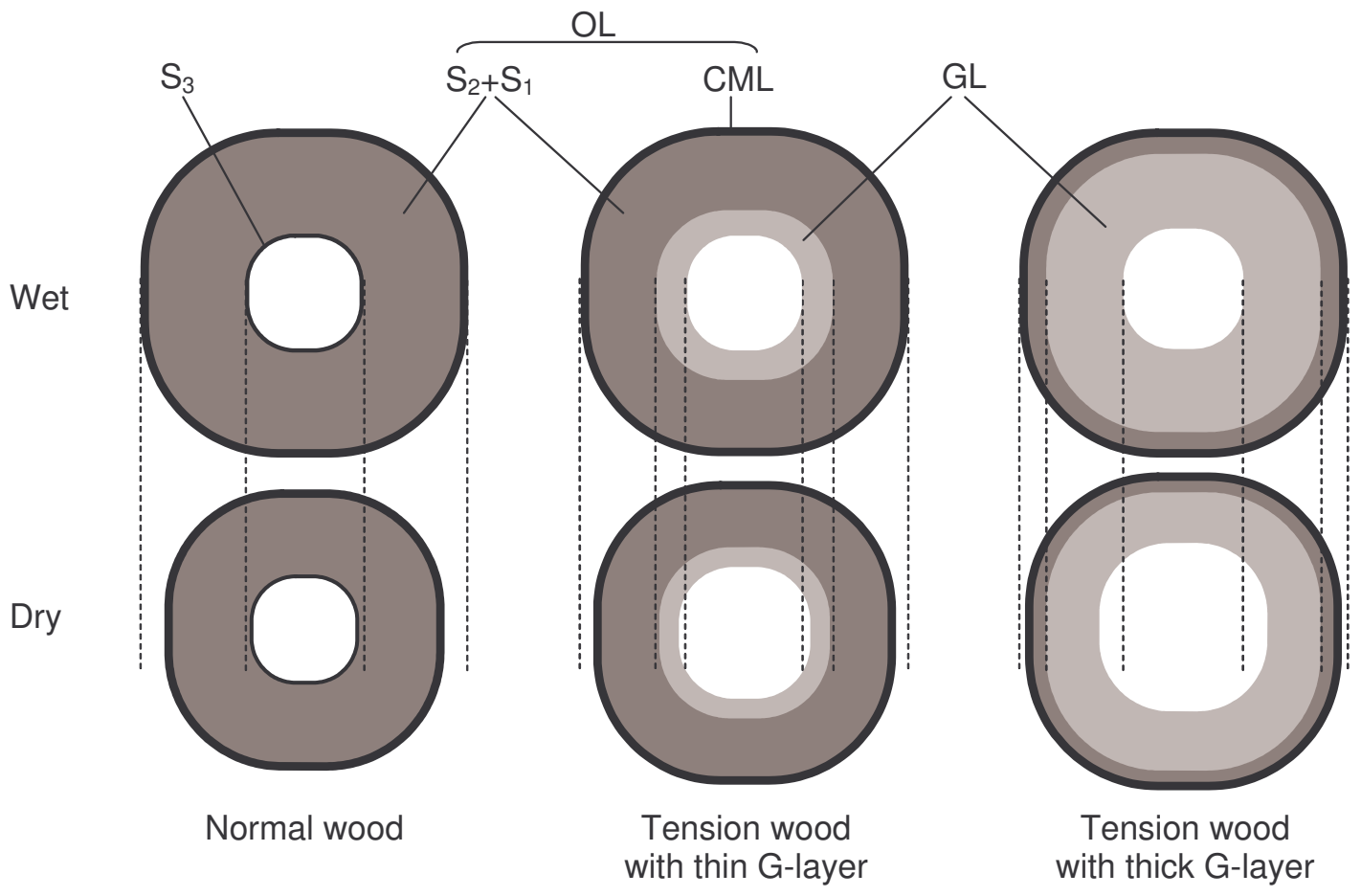

Fig. 8. 3 shrinkage scenarios starting from the same cell and lumen size, depending on the proportion of the cell wall layers. OL: other layers; CML: compound middle lamella; GL: gelatinous layer.

\section{Conclusion}

From this study the following conclusions are drawn:

- The thickness of normal wood cell wall was notably lower than that of the tension wood cell wall including GL but markedly larger than that of the other layers excluding GL. In tension wood the thickness of GL and OL increased and decreased, respectively, with the increase of GS.

- The drying shrinkage, measured as a relative thickness decrease, was significantly higher for GL than OL. There were not significant correlations between GS and GL or AL shrinkage, but a negative one was observed with OL shrinkage.

- In G-fibre, lumen size increased during drying and this increase was positively related with GS, but in normal wood fibre lumen size decreased during drying in our observations. These findings suggest that GL shrank outwards, so that its shrinkage feebly affected the total cell shrinkage and the mesoscopic shrinkage was controlled by the OL shrinkage which shrank inwards.

- At tissue level, based on the observations on sections T shrinkage was notably higher than $\mathrm{R}$ both in normal and tension wood. Both $\mathrm{T}$ and $\mathrm{R}$ shrinkages were negatively correlated with GS; however, the correlation was clear for T but weak for R.

\section{REFERENCES}

Arganbright DG, Bensend DW, Manwiller FG (1970) Influence of gelatinous fibers on the shrinkage of silver maple. Wood Science 3:83-89

Barefoot AC (1963) Selected wood characteristics of young yellow-poplar. Part II: Shrinkage of normal and abnormal wood. Forest Products Journal 13:443-448 
Bosshard HH (1956) Uber die anisotropie der holzschwindung. Holz Als Roh-Und Werkstoff $14: 285$

Chow KY (1946) A comparative study of the structure and composition of tension wood in beech (Fagus sylvatica L.). Forestry 20:62-77

Clair B, Thibaut B (2001) Shrinkage of the Gelatinous Layer of Poplar and Beech Tension Wood. IAWA Journal 22:121-131

Clair B, Jaouen G, Beauchêne J, Fournier M (2003a) Mapping radial, tangential and longitudinal shrinkages and relation to tension wood in discs of the tropical tree Symphonia globulifera. Holzforschung 57:665-671

Clair B, Ruelle J, Thibaut B (2003b) Relationship between growth stresses, mechano-physical properties and proportion of fibres with gelatinous layer in chestnut (Castanea Sativa Mill.). Holzforschung 57:189-195

Clair B, Thibaut B, Sugiyama J (2005a) On the detachment of the gelatinous layer in tension wood fiber. Journal of Wood Science 51:218-221

Clair B, Gril J, Baba K, Thibaut B, Sugiyama J (2005b) Precautions for the structural analysis of the gelatinous layer in tension wood. IAWA Journal 26:189-195

Clarke SH (1937) The distribution, structure and properties of tension wood in beech (Fagus sylvatica L.). Journal of Forestry 11:85-91

Côté WAJ, Day AC, Timell TE (1969) A contribution to the ultrastructure of tension wood fibers. Wood Science and Technology 3:257-271

Fang C-H, Clair B, Gril J, Liu S-Q (submitted 2006) Contribution of the gelatinous layer to the growth stresses generation in tension wood. Trees - Structure and function (Under review)

Fisher JB, Stevenson JW (1981) Occurence of reaction wood in branches of Dicotyledons and its role in tree architecture. Botanical Gazette 142:82-95

Fournier M, Chanson B, Thibaut B, Guitard D (1994) Measurement of residual growth strains at the stem surface. Observations of different species (in French). Ann Sci For 51:249-266

Fujita M, Saiki H, Harada H (1974) Electron microscopy of microtubules and cellulose microfibrils in secondary wall formation of poplar tension wood fibers. Mokuzai Gakkaishi 20:147-156

Furuya N, Tatahashi S, M M (1970) The chemical composition of the gelatinous layer from the tension wood of Populus euro-americana. Mokuzai Gakkaishi: 16:26-30

Isebrands JG, Bensend DW (1972) Incidence and structure of gelatinous fibers within rapid-growing eastern cottonwood. Wood and Fiber Science 4:61-71

Jourez B, Riboux A, Leclercq A (2001) Comparison of basic density and longitudinal shrinkage in tension wood and opposite wood in young stems of Populus euramericana cv. Ghoy when subjected to a gravitational stimulus. Canadian journal of forest research 31:1676-1683

Kelsey KE (1963) A critical review of the relationship between the shrinkage and structure of wood. Commonwealth scientific and industrial research organization Australia.

Keylwerth R (1951) Die anisotrope Elastizität des Holzes und der Lagenholzer [Anisotropy of elasticity of wood and wood-based materials]. VDJ - Forschungsheft 430, Düsseldorf [in German].

Kuo CM, Timell TE (1969) Isolation and characterization of a galactan from tension wood of American Beech (Fagus grandifolia Ehrl.). Svensk Papperstidn 72:703-716

Meylan BA (1972) The Influence of microfibril angle on the longitudinal shrinkage-moisture content relationship. Wood Science and Technology 6:293-301

Norberg PH, Meier H (1966) Physical and chemical properties of the gelatinous layer in tension wood fibre of aspen (Populus tremula L.). Holzforschung 20:174-178

Okumura S, Harada H, Saiki H (1977) Thickness variation of the G-layer along a mature and a differentiating tension wood fiber in Populus euramericana. Wood science and technology $11: 23-32$

Onaka F (1949) Studies on compression and tension wood. Wood research, Bulletin of the Wood research Institute, Kyoto University, Japan 24:1-88

Panshin AJ, Zeeuw Cd (1980) Textbook of Wood Technology, 4th edn. Mc Graw-Hill Book Company. New York.

Pilate G, Chabbert B, Cathala B, Yoshinaga A, Leplé J-C, Laurans F, Lapierre C, Ruel K (2004) Lignification and tension wood. Comptes rendus biologies 327:889-901

Rasband WS (1997-2006) ImageJ. U. S. National Institutes of Health, Bethesda, Maryland, USA, http://rsb.info.nih.gov/ij/

Saiki H, Ono K (1971) Cell wall organization of gelatinous fibers in tension wood. Bull. Kyoto Univ. For. 42:210-220

Sassus F (1998) Déformations de maturation et propriétés du bois de tension chez le hêtre et le peuplier : mesures et modèles. Thesis. Ph.D. ENGREF Montpellier, France [in French] 
Skaar C (1988) Wood-water relations. Springer Verlag.

Timell TE (1969) The chemical composition of tension wood. Svensk Papperstidn 72:173-181

Timell TE (1986) Compression wood in Gymnosperms 1 Biblioraphy, historical background, determination, structure, chemistry, topochemistry, physical properties, origin,and formation of compression wood. Springer Verlag.

Wada M, Okano T, Sugiyama J, Horii F (1995) Characterization of tension and normally lignified wood cellulose in Populus maximowiczii. Cellulose 2:223-233

Wardrop AB (1964) Reaction anatomy of arborescent angiosperms, in: H. Zimmermann (Ed.), The formation of wood in forest tree, New York. London, Academic Press.

Washusen R, Ilic J (2001) Relationship between transverse shrinkage and tension wood from three provenances of Eucalyptus globulus Labill. Holz als Roh und Werkstoff 59:85-93

Yoshida M, Okuyama T (2002) Techniques for measuring growth stress on the xylem surface using strain and dial gauges. Holzforschung 56:461-467 